MIROSLAV VUJIĆ, Ph.D.

E-mail: miroslav.vujic@fpz.hr

SADKO MANDŽUKA, Ph.D.

E-mail: sadko.mandzuka@fpz.hr

MARTIN GREGURIĆ, mag. ing. traff.

E-mail: martin.greguric@fpz.hr

University of Zagreb,

Faculty of Transport and Traffic Sciences

Vukelićeva 4, 10000 Zagreb, Croatia
Transport Telematics

Preliminary Communication

Submitted: Jan. 30, 2015

Approved: May 27, 2015

\title{
PILOT IMPLEMENTATION OF PUBLIC TRANSPORT PRIORITY IN THE CITY OF ZAGREB
}

\begin{abstract}
The problem with traffic congestion is particularly expressed in urban areas where possibilities for physical in crement of capacity are limited or impossible. Significant in the approach to solving this problem is the usage of Public Transport (PT) and the implementation of various advanced control measures that can improve the quality of overall public transport system. The main objective of this research is to explore the possibilities of implementation of adaptive traffic control on signalized intersections giving priority to public transport vehicles through urban traffic network in the city of Zagreb. The possibilities of implementing public transport priority (PTP) technique in the city of Zagreb are analyzed because of specific traffic situations on defined corridors (location of stops, distance between intersections, etc.). With proper usage of PTP techniques (e.g. adequate detector positions, good estimation of PT vehicle arrival time at intersection) the total tram travel time can be significantly reduced. The Level of Service at intersection may be approximately retained because cross-street traffic demand was not ignored. According to technological level of traffic control system in the city of Zagreb, global implementation of PTP is not possible. So, for each intersection the PTP algorithm was developed separately, but mutual traffic influence of all intersections on the corridor was considered. The cooperative concept application within urban traffic control is considered as well.
\end{abstract}

\section{KEY WORDS}

intelligent transport systems; adaptive traffic control; public transport priority; cooperative systems;

\section{INTRODUCTION}

One approach to improving the urban traffic system quality is the origination of significant usage of public transport system. In order to stimulate end users to switch from passenger vehicles to PT it is necessary to improve the PT system quality in general. This can be achieved by applying certain measures that can improve the quality of public transport. The measures for public transport quality improvement can be divided into four basic categories [1, 2]:

1. Roadway (infrastructure) improvements - the simplest type of measures that include minor changes to roadways, relocation of PT stops, improved traffic regulations, etc.

2. Improvement of PT system operations - improved PT management centre, design of PT vehicles, modifications in payment methods.

3. Administrative measures - congestion charging, limitations for delivery vehicles in urban areas.

4. Adaptive traffic control - usage of control strategies on signalized intersections with PTP techniques.

The effectiveness of proposed measures depends on the level of implementation of measures and their mutual combination. Four levels of measure implementation are defined [2]:

1. Limited implementation - measures are implemented individually on different locations of traffic network, with priority given to critical intersections;

2. Route level implementation - measures are implemented on entire route of PT network (all signalized intersections along the route, all PT stops, etc.);

3. Area-wide implementation - measures are implemented on specific parts of traffic network (urban zones with greater number of PT lines with limited access to private vehicles);

4. General implementation - measures are implemented to all PT lines and routes and the operative concept of traffic management is changed.

Public Transport Management Systems (PTMS) are systems that use information and communication 
technologies in order to increase efficiency and safety of PT systems and to provide the PT users with greater access to information on system operations [3]. The implementation of PTMS improves the PT operations and services that can be offered by advanced PT systems.

The scope of PTMS can be organized into four main categories:

1. fleet management,

2. traveller information,

3. electronic payment, and

4. transportation demand management.

Also, PTMS can be described through some of the functional areas of Intelligent Transportation Systems (ITS) regarding public transport: fleet operation and management, fare collection, traveller information systems [4].

Additional PTMS could be enhanced with the implementation of cooperative approach. With cooperative concept in dynamic traffic control, it is possible to expand the existing communication between three main subsystems of urban traffic system: vehicle, infrastructure and driver. Besides basic traffic information (PT lane number, delay regarding predefined timetable, present location of PT vehicle, etc.) it is possible to provide additional traffic data:

- Frequency of PT vehicles on specific route;

- Arrival time of the following vehicle;

- Current number of passengers in specific PT vehicle;

- Queue lengths on every intersection approach;

- Frequency of PTP activation status, etc.

Figure 1 shows the concept of PTMS scenario which is improved with the cooperative concept.

Direct benefits of cooperative concept include the possibility to use and implement advanced PTP techniques without ad-hoc investments in infrastructure and PT vehicles. Also, cooperative systems can contribute to mobility rationalization in terms of conges-

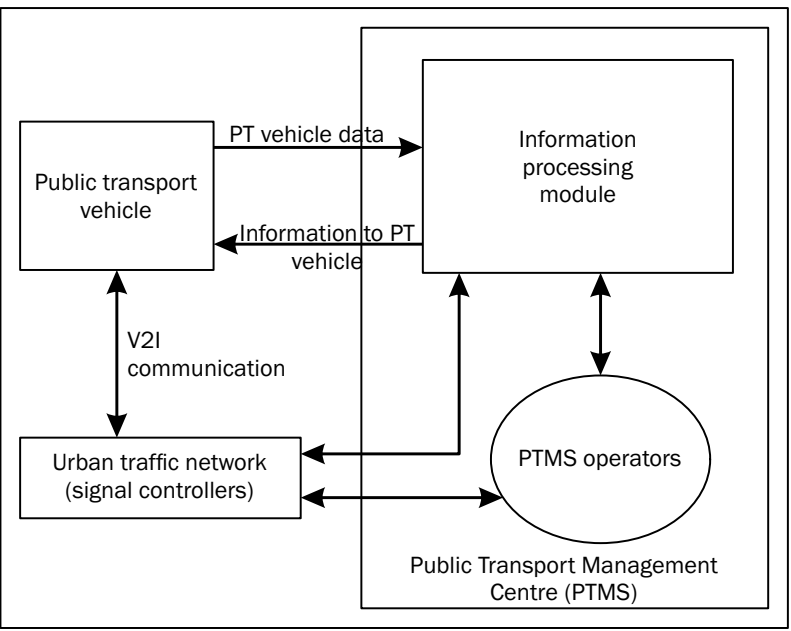

Figure 1 - Improving public transport management system by cooperative approach tion reduction, increment of average speed, reduction of traffic noise and emission of $\mathrm{CO}_{2}$, etc. [5]. In addition to safety benefits, significant environmental and productivity benefits can be achieved as result of cooperative concept - improvement in driving efficiency, routing and congestion management. Cooperative approach in urban traffic control is essential in the development of new concepts because vehicles, infrastructure and drivers are no longer self-dependent they cooperate in order to improve the quality of traffic system in general.

According to the above mentioned measures for public transport quality improvement (e.g. adaptive traffic control) this research will be focused on the possibilities of their implementation in the city of Zagreb. Two implementation scenarios with simulation results will be presented. Also, cooperative concept of traffic control will be considered as the basis of future research.

Section 2 describes the existing PTP strategies and techniques that are widely used in urban traffic control (for enhancement of the PT system quality). The case study with two locations in the city of Zagreb is presented in Section 3, with simulation model results and evaluation. In Section 4 the methodology for definition of improved traffic control (with cooperative approach) is presented. Some discussions on the achieved results (advantages and disadvantages of applied techniques, etc.) are described in Section 5. The concluding observations with recommendations for future research are given in Section 6.

\section{PUBLIC TRANSPORT PRIORITY STRATEGIES}

Delays of public transport vehicles on signalized intersections include $27 \%$ - 35\% of all delays induced by all traffic in urban network (including public transport) [6]. Advanced adaptive control of signalized intersections includes providing green lights to public transport vehicles whenever possible. Three main approaches in PTP assignments are defined as:

- passive approach,

- unconditional approach,

- active approach.

The predefined signal plans are used when implementing passive priority approach which contributes to reducing public transport vehicle travel times. Passive priority approach does not need the presence of public transport vehicle, nor notification of its arrival to a signalized intersection. Specific passive priority techniques include cycle length reduction and phase splitting.

Public transport vehicles have unconditional priority given on signalized intersection no matter which phase of the cycle is active. After the end of the active 
phase (considering minimal safety/passenger green times), green light for public transport vehicles is immediately activated. Unconditional approach is rarely used in public transport, but it is widely used for emergency and VIP vehicles priority assignment.

Active priority techniques are activated only when public transport vehicle is present at signalized intersection, or when priority demand is sent to the control centre. After the demand is sent, the priority technique is activated within the limits of minimal safety parameters.

Active approach techniques include green phase extension, early green phase (red truncation), green phase insertion, phase rotation or substitution and selective strategies.

\section{a) Green phase extension}

If public transport vehicle approaches a signalized intersection, and green light is active, it can be extended for the time a public transport vehicle needs to pass through the intersection (Figure 2). Maximum extension limit is used to limit the impact on crossstreet vehicles.

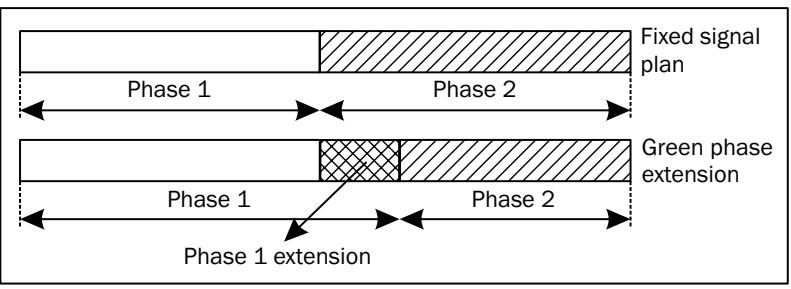

Figure 2 - Green phase extension technique

Different projects and references define maximum green extension times which in implemented scenarios differ from $10 \mathrm{~s}$ to $20 \mathrm{~s}$ [7].

\section{b) Early green phase (red truncation)}

If public transport vehicle approaches a signalized intersection, and red light is active, it can be shortened so that early green phase can be activated (Figure 3).

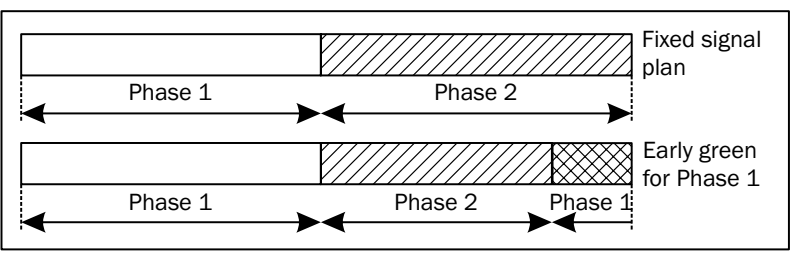

Figure 3 - Early green phase (red truncation) technique
Maximum red truncation values are lower than green extension values because red truncation depends on the inter-green matrix (minimum time necessary for pedestrians to cross the road).

\section{c) Green phase insertion}

If public transport vehicle approaches a signalized intersection (with three or more signal phases) it is possible to insert green light (which is not in the signal expected in the cycle) for the approaching public transport vehicle (Figure 4).

A certain phase of the signal cycle can be withdrawn when there is no traffic load on the respective lane. In that case, it is possible to activate green light for the approaching public transport vehicle and reduce public transport vehicle delay. After PT vehicle detection, the system calculates the predicted time of vehicle arrival on the signalized intersection.

\section{CASE STUDY: DYNAMIC PTP IN THE CITY OF ZAGREB}

For reliable and valid results and evaluation, real traffic corridors in the city of Zagreb were selected. Traffic data were gathered for the calibration of simulation model and for modelling of PT traffic, which will be presented in this Section.

\subsection{Description of demonstration corridors}

For reliable simulation and inquiry of PTP implementation two critical corridors in the city of Zagreb were selected. One of the main traffic problems of the city of Zagreb is the user's daily fluctuation from east to west and vice versa. The traffic corridor of Zvonimirova Street represents the main link of the Zagreb centre and the east part of the city (Figure 5). The demonstration corridor is 2,690 metres long, traffic is bidirectional, with separate $\mathrm{PT}$ lines and road traffic.

On the selected corridor there are 24 intersections and eight of them are signalized with fixed control logic. Signal controllers operate in coordination with the exception of the last intersection (Zvonimirova Street Budakova Street). There are six PT stops in both directions, but four of them are set just before the signalized intersections. These specific traffic situations are suitable for the definition of cooperative zone concept, because classic dynamic traffic control methods can-

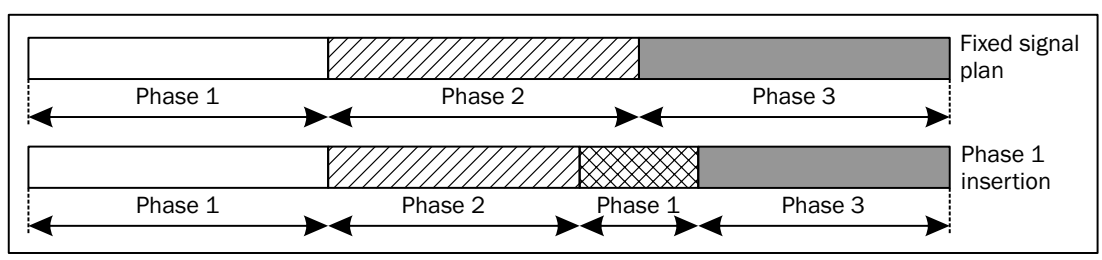

Figure 4 - Green phase insertion technique 


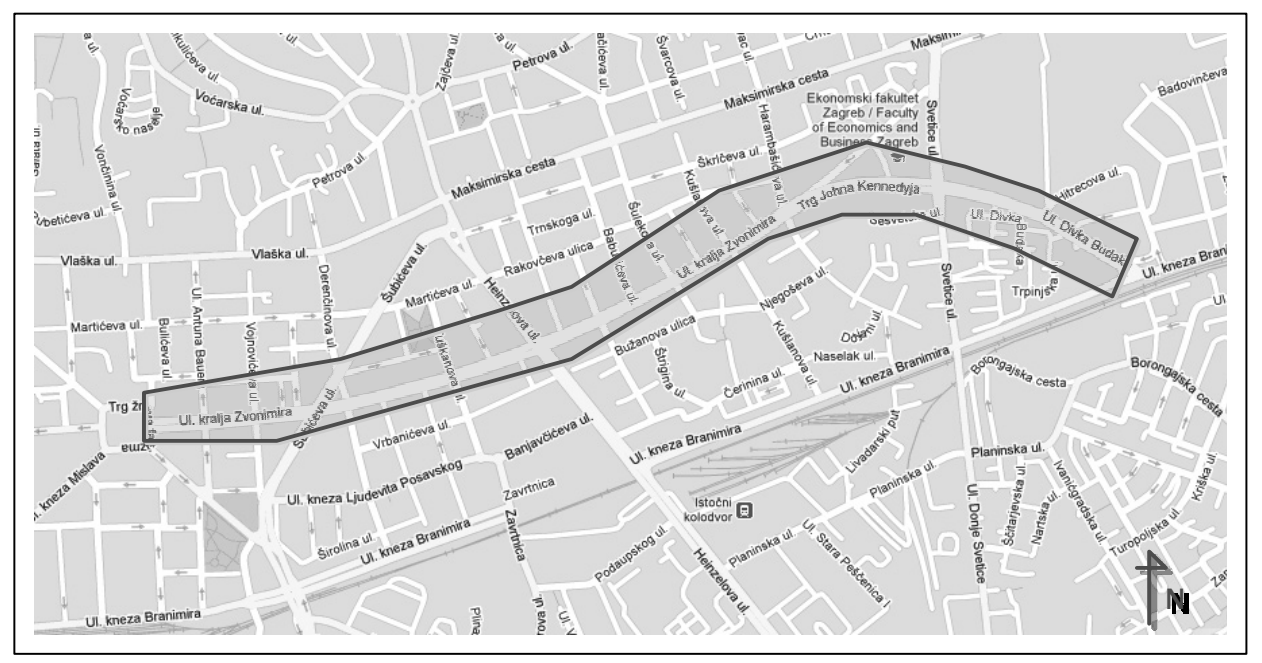

Figure 5 - Zvonimirova Street demonstration corridor

not be implemented (lack of time and space for normal PTP algorithm implementation).

The other corridor is Savska Street and Frankopanska Street in the city of Zagreb [8]. The corridor is 3.2 kilometers long, and it connects the historic City centre (in the north) with multidirectional intersection (one of the main entries into the City) on the southern part of the corridor (Figure 6).

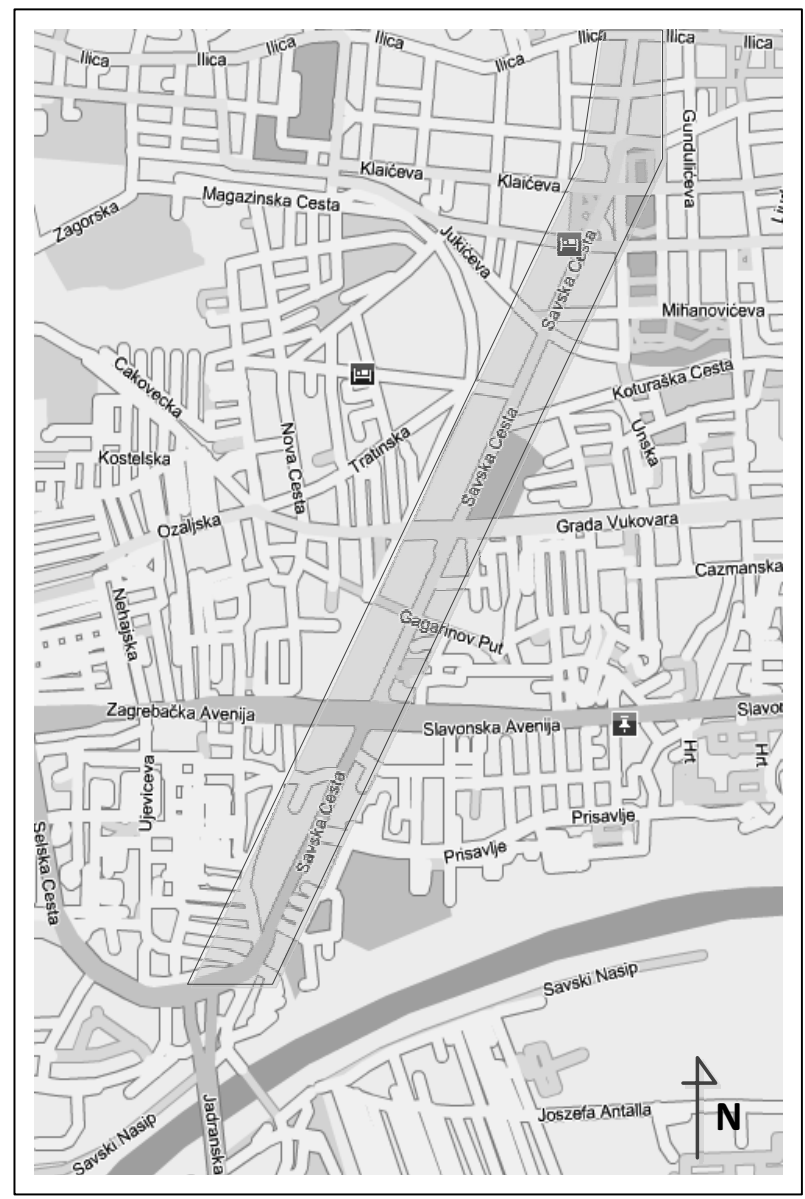

Figure 6 - Savska Street and Frankopanska Street demonstration corridor
Traffic along the corridor operates in both directions, with passenger and public transport vehicles travelling at one level. Exceptions are small parts of the street where there are reserved lanes for public transport. Along the corridor there are 12 intersections, all of them equipped with horizontal and vertical traffic signalization and fixed signal control. Controller coordination does not exist along the whole corridor, but there are five coordinated segments. Coordination issues and obsolete signal controller devices cause great difficulties in PTP implementation (the oldest signal controller is PSV/TESLA, 1977). The only possible solution is adaptive traffic control of each intersection separately. Also, the problem of implementing priority techniques is cross-street vehicle volume on the majority of intersections, where cross-street traffic is much greater than on the demonstration corridor. Savska Street is one of the busiest streets in the City of Zagreb, which is most obvious during the morning and afternoon peak hours. Even though reserved tram lines do exist, personal vehicle drivers do not respect them entirely, which causes significant increase in tram travel times and dwell times at stops before intersections. All intersections are equipped with signal controllers.

\subsection{Simulation and PT algorithm development}

Simulation model was made in PTV VISSIM simulation tool, with the addition of PTV VisVAP module (Vehicle Actuated Programming) for development and implementation of PTP control algorithms. Relevant traffic data (number and classification of vehicles, PT vehicle frequency, speed, dwell time, etc.) were collected, and the simulation model was properly calibrated. It was not possible to achieve cooperative priority due to the lack of PTV module for the development of cooperative priority algorithms. Cooperation (communication link) was achieved at low level communication 
between PT vehicles and infrastructure (partial V2I communication) where PT vehicle sends relevant information about timetable delay to local signal controller which then activates PTP algorithms at each signalized intersection.

In the first scenario (Zvonimirova Street), PTP algorithm is activated only when the phase where PT lines operate is active. Active PTP technique "green extension" was mostly used and activated only when PT vehicle does not have enough time to pass through the intersection. The second scenario (Savska Street) includes different methods and PTP techniques according to specific traffic signal timings at signalized intersections. Optimal PTP technique was chosen with the best benefits for PT system (PT delay, travel times, etc.). In this case, passive PTP techniques were also implemented. After PT vehicle sends information to local signal controller about the delay in predefined timetable and that PT vehicle is detected on installed detectors inside the road, the duration of PT phase is taken [9]. If the controller calculates that PT vehicle does not have enough time to pass through the intersection, the PT phase is extended according to its present distance from the intersection.

\subsection{Results and evaluation}

After the completion of simulation of the existing and PTP model, the results were gathered and the evaluation was conducted. One of the main performance indicators of adaptive (improved) traffic control is the average travel time $[10,11]$. Travel times are measured for every PT line and PT vehicle, so average values were calculated. According to simulation results, eastbound PT line's existing average travel time was 671.1 seconds, and after implemen-

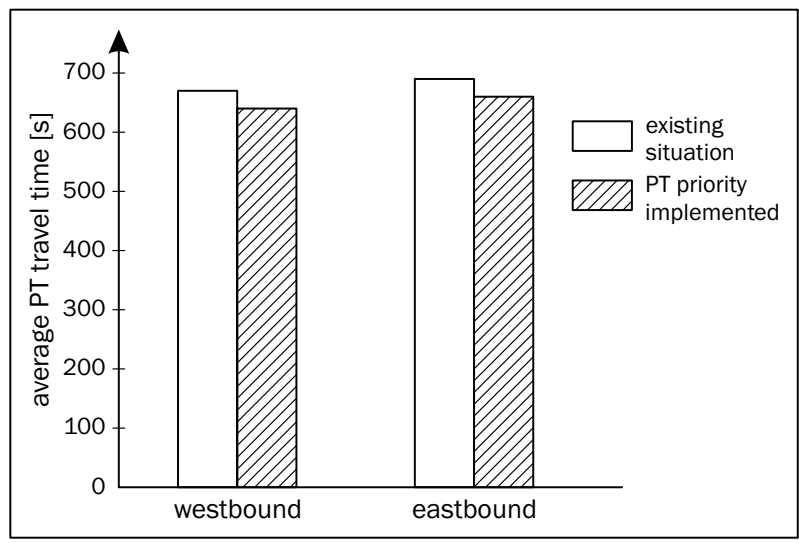

Graph 1 - Graphical representation of average PT travel times

tation of PTP algorithms the average travel time was 650.5 seconds, which is 20.6 seconds less. In the other direction (westbound direction towards the city centre) average travel time for the present state was 696.8 seconds, and with the implementation of PTP algorithms the average travel time was $665.5 \mathrm{sec}-$ onds (with 31.3 seconds shorter average travel time). The comparison of average travel times of the present state and with improved traffic control is shown in Graph 1.

Average PT travel time was also separated on sections along the selected corridor in order to compare the effects of PTP algorithms on every signalized intersection. Graph 2 shows comparison of travel times through every signalized intersection for both PT line directions (westbound and eastbound).

From the presented results of average PT travel times ("before" and "after") it is noticeable that with right implementation of PTP algorithms it is possible to reduce the average PT travel time on the

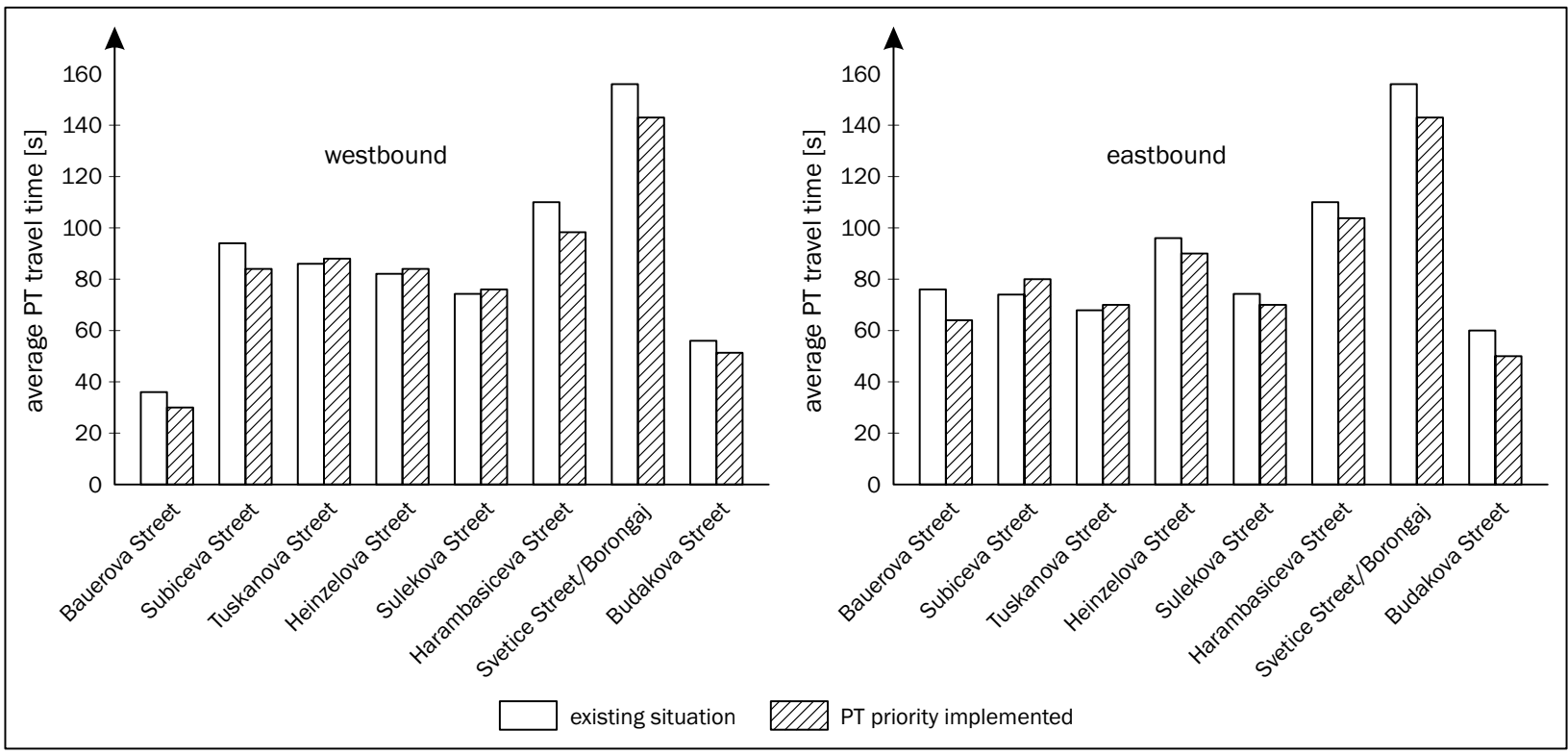

Graph 2 - Sectioned PT travel times through signalized intersections (westbound and eastbound) 
M. Vujić, S. Mandžuka, M. Gregurić: Pilot Implementation of Public Transport Priority in The City of Zagreb

Table 1 - Average delay and Level of Service comparison on the corridor before and after PTP implementation

\begin{tabular}{||l|c|c|c|c||}
\hline \multicolumn{1}{|c|}{ Signalized intersection } & $\begin{array}{c}\text { Present state } \\
\text { average delay } \\
{[\mathrm{s} / \text { veh] }}\end{array}$ & $\begin{array}{c}\text { Present } \\
\text { state } \\
\text { LoS }\end{array}$ & $\begin{array}{c}\text { Average delay with } \\
\text { implemented PTP } \\
\text { [s/veh] }\end{array}$ & $\begin{array}{c}\text { Level of Service with } \\
\text { implemented } \\
\text { PTP }\end{array}$ \\
\hline \hline Bauerova Street - Zvonimirova Street & 12,2 & $\mathrm{~B}$ & 14,4 & $\mathrm{~B}$ \\
\hline Subiceva Street - Zvonimirova Street & 23 & $\mathrm{C}$ & 24.6 & $\mathrm{C}$ \\
\hline Tuskanova Street - Zvonimirova Street & 7 & $\mathrm{~A}$ & 10.3 & $\mathrm{~B}$ \\
\hline Heinzelova Street - Zvonimirova Street & 21.7 & $\mathrm{C}$ & 26.1 & $\mathrm{C}$ \\
\hline Sulekova Street - Zvonimirova Street & 12 & $\mathrm{~B}$ & 11.9 & $\mathrm{~B}$ \\
\hline Harambasiceva Street - Zvonimirova Street & 16.6 & $\mathrm{~B}$ & 13.8 & $\mathrm{~B}$ \\
\hline Svetice Street - Zvonimirova Street & 27.5 & $\mathrm{C}$ & 28 & $\mathrm{C}$ \\
\hline Budakova Street - Borongaj & 17.8 & $\mathrm{~B}$ & 14.3 & $\mathrm{~B}$ \\
\hline
\end{tabular}

part of traffic network. The relatively small reduction in average travel times is the result of several factors:

- The simulation model was performed for the morning peak hour and full benefits of PTP implementation can be visible over a longer time period (i.e. month, year, etc.);

- Case study corridor was only 2,500 metres long and PTP algorithms were implemented on only six signalized intersections. With the right implementation of PTP algorithms on a greater part of the traffic network (one or more PT routes), significant savings in average travel times can be achieved;

- The implementation of PTP algorithms directly affects the PT systems quality, and it is supposed that a greater number of users would transfer to public transport and average dwell times would be increased, too.

In association with the average PT travel times are values of average PT speeds, and it is expected that the average speed would be increased if the average travel time was reduced. In this particular research, the westbound PT line average speed was increased from $13.4 \mathrm{~km} / \mathrm{h}$ to $14.0 \mathrm{~km} / \mathrm{h}$, and eastbound average speed was increased from $12.9 \mathrm{~km} / \mathrm{h}$ to $13.5 \mathrm{~km} / \mathrm{h}$.

Another relevant performance indicator is the Level of Service (LoS) of the intersection. When PTP is implemented, signal cycle is not fixed, and phase times directly affect cross-street traffic. The impact and activation of PTP algorithms must be limited, so that LoS would not be significantly reduced. The comparison of LoS on the present state model and on the model with the implemented PTP is shown in Table 1.

Table 1 shows that LoS is kept at almost all intersections but one (Tuskanova Street - Zvonimirova Street). The specific situation (number of vehicles, position of PT stops, etc.) determines the reduction of LoS at that signalized intersection. Also, it should be noted that with the implementation of PTP a larger number of passengers can be transported in shorter time periods.

\section{ADVANCED POTENTIALS OF PTP COOPERATIVE APPROACH}

The next possible step in the improvement of public transport management system could be the expansion with the cooperative concept, mostly in the field of dynamic traffic control (at signalized intersections). Cooperative approach includes communication among three main factors in traffic and transport system - vehicle, infrastructure and driver. So, basically, there are two main communication channels: vehicle-to-vehicle (V2V) and vehicle-to-infrastructure (V2I) communication.

Also, this research includes conceptual cooperative model for future applications of PTP as part of EU FP7 STREP project Intelligent Cooperative Sensing for Improved Traffic Efficiency - ICSI [12]. The ICSI cooperative concept is composed of heterogeneous subsystems and components (Figure 7):

Information and collected data are processed in a cooperative manner performing content aggregation since the earliest stages, e.g. information about traffic flows can be collected through WSNs based on low-cost camera sensors and stored locally, sending statistical data to the Control Centre, for long-term evaluation. In order to do that, ICSI defines two key concepts:

- ICSI gateway (GW) - it hosts the Data Distribution Platforms and the high level applications in charge to enable local intelligence in the system. GWs allow data exchange with attached sub-systems such as WSNs and vehicular networks, and can share data with other GWs achieving collaborative sensing and events notification.

- ICSI areas. The concept of area is related to the context in which the gateway works. Areas can be classified into local and global areas:

- A local area is a set of gateways that cooperate in order to offer cooperative sensing to services and applications. A gateway can join one or more local areas. Gateways that join an area 


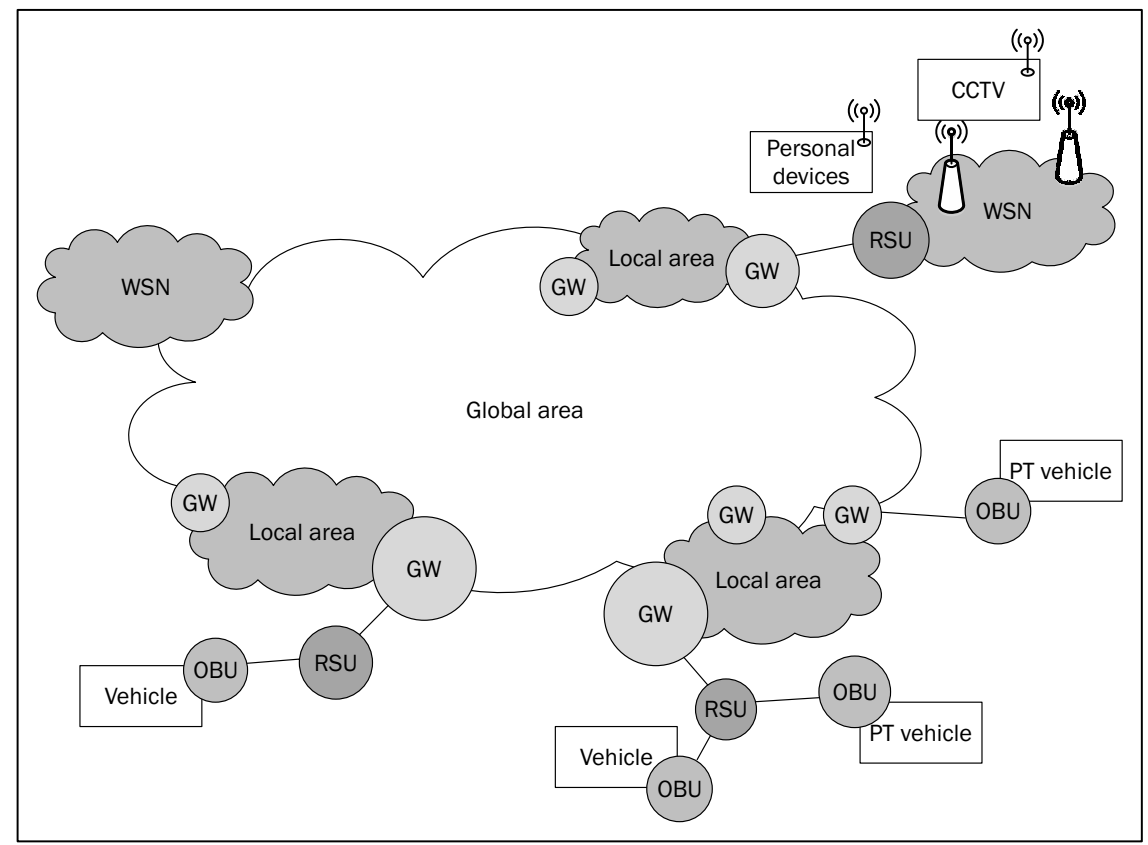

Figure 7 - ICSI system architecture [12]

are selected according to geographical, urban or strategic considerations in order to make it possible for each gateway to take local decisions based on the input provided by its attached subsystems (e.g. vehicular subsystem, wireless sensor network subsystem) and by other ICSI gateways in the same area.

- The global area is the overlay network connecting all the ICSI gateways in the system. The global area allows long-term and statistical data collection and remote monitoring capabilities to control centres.

Figure 8 represents the basic concept of defined ICSI cooperative PTP approach.

As shown in Figure 8, the enhanced vehicle enters the cooperative control zone and cooperative control mode is enabled. The vehicle sends expanded set of information (vehicle location and speed, current number of passengers, possible delays according to predefined timetables, etc.) to Traffic Management Centre - TMC. V2I communication is achieved between vehicle and TMC. According to received information and current traffic situation TMC makes a decision about the need for PTP activation, and selects the favourable PTP technique [13].

In cases of incident in the cooperative control zone TMC sends real-time information to the driver (detailed information about the incident, expected delay, alternative routing, etc.) who then manually makes the decision about next actions. It can be seen that cooperation is achieved within traffic and transport system, and the improved system enables the observation of the driver, vehicle and infrastructure as one unified (upgraded) system.
With cooperative (advanced) approach the public transport system can be observed as one unique system, with real-time communication between vehicles and infrastructure. When minimal technical requirements are achieved in the city of Zagreb (advanced signal controllers, coordination of signal controllers, etc.) cooperative control should be considered because of advantages of cooperative control: travel for end-users would be comfortable, PT vehicles would travel with fewer stop-and-go actions, steady travel speeds, etc. which leads to energy savings, fewer operating vehicles and better public transport service quality in general.

\section{DISCUSSION}

This research was based on real traffic situation and gathered traffic data in the city of Zagreb. The current state simulation model was developed and calibrated with PTV VISSIM simulation software, and PTP algorithms were developed specifically for every signalized intersection on the selected corridor. The main PT performance indicator (average travel time) was reduced by $4 \%$ (reduction of $20-30$ seconds per PT vehicle), and accordingly, the average PT vehicle speed was increased by $5 \%$. The main reason for relatively small indicator improvement was the specific traffic situation of the selected corridor - PT stops are situated just before the signalized intersection, so time interval for PTP execution was very limited. One solution for additional improvement can be the relocation of PT stops after signalized intersections and/or upgrading the traffic control system with cooperative concept which includes realization of real-time communication between PT vehicle and PTMS. 


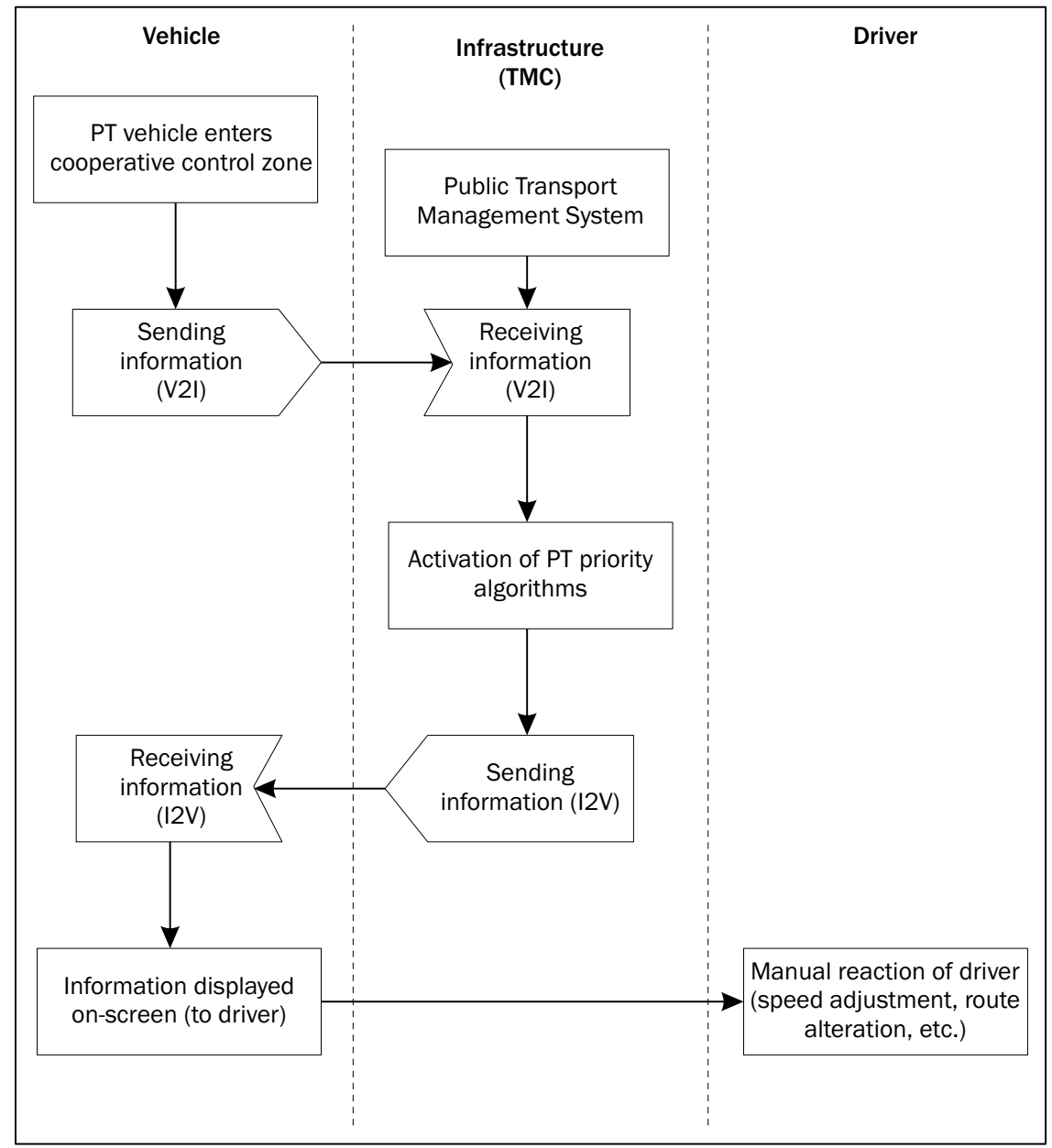

Figure 8 - Basic diagram of cooperative PTP scenario [13]

This research was based on PTP implementation in case when PT vehicles do not interfere with other road vehicles (unmixed traffic flow). The problem is more complex when all vehicles interfere mutually (mixed traffic flow). The main problem is the estimation of PT vehicle arrival time to intersections. This will be the goal of future research.

The benefits of cooperative concept include the possibility to detect specific vehicles (e.g. vehicle with more boarded passengers) and vehicle categories (e.g. freight vehicles, delivery trucks, etc.). Also, cooperative systems can contribute to mobility rationalization in terms of congestion reduction, increment of average speed, reduction of traffic noise and emission of $\mathrm{CO}_{2}$, etc. In addition to safety benefits, significant environmental and productivity benefits can be achieved as result of cooperative concept - improvement in driving efficiency, routing and congestion management.

\section{CONCLUSION}

This research shows that certain measures should be implemented on public transport system and that dynamic (adaptive) traffic control and improved public transport management system are the most efficient measures (when properly implemented). This research proved that with well-developed PTP algorithms for every specific traffic situation the average public transport travel time can be decreased without major impacts on other road traffic (Level of Service remains mostly the same). Cooperative systems can potentially provide a platform for innovative solutions to improve traffic flows, better information on trip times and improved travel planning and control.

Modern public transport management systems can provide major improvement for end users (additional traveller information, accurate timetables etc.), especially when upgraded with cooperative concept - enabled communication (expanded set of traffic information) within infrastructure, vehicles and drivers. For these reasons, this important area of urban traffic management system is implemented as a priority measure in the Croatian National program for the development and deployment of ITS and road traffic on priority areas for the 2014-2018 period [14]. 


\section{ACKNOWLEDGEMENT}

The research reported in this paper is funded by the European Union FP7 STREP project co-funded by the European Commission under the ICT theme (Call 8) of DG CONNECT (FP7-317671)

Dr. Sc. MIROSLAV VUJIĆ

E-mail: miroslav.vujic@fpz.hr

Prof. dr. sc. SADKO MANDŽUKA

E-mail: sadko.mandzuka@fpz.hr

MARTIN GREGURIĆ, mag. ing. traff.

E-mail: martin.greguric@fpz.hr

Sveučilište u Zagrebu, Fakultet prometnih znanosti

Vukelićeva 4, 10000 Zagreb, Hrvatska

\section{SAŽETAK}

\section{PILOT IMPLEMENTACIJA DODJELE PRIORITETA VOZILIMA JAVNOGA GRADSKOGA PRIJEVOZA U GRADU ZAGREBU}

Problem zagušenja prometa posebno je izražen u gradskim područjima gdje su mogućnosti fizičkog povećanja kapaciteta prometnica ograničene ili nemoguće. Jedan od pristupa pri rješavanju navedenog problema je povećano korištenje javnoga gradskoga prijevoza (JGP), te implementacija različitih naprednih mjera koje mogu poboljšati kvalitetu sustava JGP-a. Glavni cilj ovog istraživanja je iznaći i predložiti mogućnosti implementacije adaptivnog upravljanja semaforiziranim raskrižjima uz dodjelu prioriteta vozilima JGP-a na prometnu mrežu grada Zagreba. Mogućnosti implementacije prioritetnih tehnika u gradu Zagrebu jesu analizirane zbog specifične prometne situacije na odabranim koridorima (smještaj stajališta JGP-a, udaljenost susjednih raskrižja, itd.). Uz pravilnu uporabu prioritetnih tehnika (npr. točne pozicije detektora, dobra procjena dolazaka vozila JGP-a na raskrižje, itd.) ukupno vrijeme putovanja vozila JGP-a može se značajno smanjiti. Razina uslužnosti semaforiziranih raskrižja može se održati iz razloga što se prometno opterećenje sporednih privoza ne zanemaruje. $\mathrm{Na}$ temelju tehnološke razvijenosti postojećeg sustava upravljanja prometom u gradu Zagrebu potpuna implementacija prioritetnih tehnika nije moguća. Iz tog razloga, algoritmi dodjele prioriteta razvijeni su za svako raskrižje posebno ali su uzeti u obzir međuodnosi susjednih raskrižja, te odabranih koridora u cjelini. Također, predstavljena je i primjena kooperativnog koncepta u upravljanju gradskim prometnim sustavom.

\section{KLUUČNE RIJEČI}

inteligentni transportni sustavi; adaptivno upravljanje semaforiziranim raskrižjima; dodjela prioriteta javnom gradskom prijevozu; kooperativni sustavi;

\section{REFERENCES}

[1] Nash A. Implementing Zurich's Transit Priority Program. Transportation Research Record \#1835. Washington D.C.: Transportation Research Board; 2003.

[2] Nash AB, Sylvia R. Implementation of Zurich's Transit Priority Program. Mineta Transportation Institute, San Jose State University; 2001.

[3] Advanced Public Transportation Systems: The State of the Art. Update 2000. Washington DC: US Department of Transportation, Federal Transit Administration; 2000.

[4] Bošnjak I. Intelligent Transport Systems I [in Croatian]. University of Zagreb, Faculty of Transport and Traffic Sciences; 2005.

[5] Molina M. An Intelligent Assistant for Public Transport Management. Advances in Intelligent Computing. Lecture Notes in Computer Science. 2005;3645:199-208.

[6] Wu Z, Zhao L, Sun J. A Study of Dynamic Right-Turn Signal Control Strategy at Mixed Traffic Flow Intersections. Promet - Traffic\&Transportation. 2014;24(6):449-458.

[7] Hounsell N, Shrestha B. A New Approach for Cooperative Bus Priority at Traffic Signals. IEEE Transactions on ITS. 2012;13(1):6-14.

[8] Vujić M, Jelušić N, Anžek M. Implementation status report on PT priority. CIVITAS ELAN Deliverable No. 8.2-D1. Final Version. Zagreb: Faculty of Transport and Traffic Sciences; 2011.

[9] Häll CH. A Framework for Evaluation and Design of an Integrated Public Transport System. Linkoping Studies in Science and Technology. Licentiate Thesis No. 1257. Norrkoping, Sweden: University of Linkoping; 2006.

[10] Vujić M. Dynamic Priority Systems for Public Transport in Urban Automatic Traffic Control [PhD Thesis, in Croatian]. Zagreb: Faculty of Transport and Traffic Sciences; 2013.

[11] Matulin M, Mrvelj Š, Jelušić N. Two-Level Evaluation of Public Transport Performances. Promet Traffic\&Transportation. 2011;23(5):329-339

[12] D1.1.1 Use Cases Definition and Analysis. FP7 ICSI Intelligent Cooperative Sensing for Improved traffic efficiency. Grant Agreement Number: 317671; 2014.

[13] D5.1.1. Rules, traffic models, travel strategies. FP7 ICSI - Intelligent Cooperative Sensing for Improved Traffic Efficiency. Grant Agreement Number: 317671; 2014.

[14] Mandžuka S, Žura M, Horvat B, Bićanić D, Mitsakis E. Directives of the European Union on Intelligent Transport Systems and their impact on the Republic of Croatia, Promet - Traffic\&Transportation. 2013;25(3):273283. 
